\title{
Dmitry Glukhowsky as a Brand: between Literary Creativity and Self-Representation
}

\author{
Eva Kozak* \\ Siedlce University of Natural Sciences \\ and Humanities \\ 39 Żytnia Str., Siedlce, 08-110, Poland
}

Received 10.01.2017, received in revised form 28.02.2017, accepted 11.04.2017

The present work attempts to examine the image of the modern Russian writer, Dmitry Glukhowsky, whose books have been translated to dozens of languages and have become base of computer games and many screen adaptations. Grate effort, like the literary output and advertising; have been connected with achieving this huge success.

Undoubted influence on literary work of the Russian's young generation writer had his education, journalist experience and unusually rich imagination inspired both by everyday events and also with creativity of notable representatives of the science fiction genre.

General part of the presented article discusses the most important problematic aspects in Dmitry Glukhowsky's work, particularly diversity of undertaken topics and unique poetics of individual novels and stories. Also, process connected with promotion and sharing books via separate web pages creation characterised with precise audio-visual editing, was mentioned here.

Due to the undeniable literary value of Russian writer's works as well as commitment with the aim of attractive and free of charge sharing his novel's content, Glukhovsky's output has become answer for 21 st century reader's demands.

Keywords: Dmitry Glukhowsky, Russian literature of the 21st century, science fiction, literature in the internet.

DOI: $10.17516 / 1997-1370-0079$.

Research area: philology.

\section{Introduction}

Just several decades ago the life of a novice writer was an uncomfortable one. Despite how much of his talent, time and even not once health he spent on creating literary works, the future of them was determined by the publisher. It was him who decided whether the book would see this world or would it be closed in the desk.

It is impossible to say the number of talented people who had to give up the literature and face the fact that the public would never learn about them since their book had not appealed to the publisher.

(C) Siberian Federal University. All rights reserved

* Corresponding author E-mail address: nkovtun@mail.ru 
Everything has changed due to the invention of the Internet. The time has come for everyone to have an opportunity to be heard and since so, not the publisher, but the readers decide the future of the writer. In the past, the book to be recognized by the readers it had to be published first. Now, those works are being published which have already been recognized by the readers in the Net.

Exactly through reflection of the novel Metro 2033 in the Internet, the readers have learnt about Dmitry Glukhowsky as a writer. He is quite young, but has already written a number of novels bringing him a global fame and became one of the pioneers of the online publications over the course of a fourteen-years literature activity online has become a brand.

Moreover, Glukhowsky is a famous international journalist, who works with the most popular news agencies, a radio host and columnist in rating publishings.

\section{Biography and career}

Dmitry Glukhowsky was born June 12, 1979 in Moscow, in the family of a journalist. It is hard to say, what determined the talent of the future fantast - whether it was inherited or formed by the family atmosphere - but his favorite toy was his father's typewriter. $\mathrm{He}$ started writing first stories when he was ten. His style and themes were influenced by the iconic fantasts of the Soviet period, i.e. by Strugatsky Brothers and Kir Bulychev, as well as by such classics of that genre as Stanislaw Lem, Isaac Asimov, Clifford Simak, Ray Bradbury. Soon, the short stories were changed into the novels and tales.

Glukhowsky finished the school named after V.D. Polenov with an in-depth study of French. Studying in the prestige school caused long-time travels within which Dmitry created new plots for his stories. One of them was based on the mix of
Fallout, a popular computer game of that time, with the fact - well-known to the capital citizens that the Moscow underground represents a highly complex communication system aimed at serving as a cover in the case of a nuclear war. The idea of transformation of the everyday reality into a fantasy space inhabited by post-apocalyptic settlements of people with different mentality has later brought the young writer to the world fame (Puminov, 2016).

Then, he lived and studied in Israel for four and a half years. Having graduated from Hebrew University of Jerusalem (his special fields are "Journalism" and "International Relationships"), Glukhowsky by the time of reaching the diploma fluently spoke five languages. In 2002 the young journalist moved to Lion (France), where he started cooperating with EuroNews, one of the European TV-channels. In 2005 the writer returned back to Russia and worked as a reporter on a renewed TV-channel called Russia Today. He was a member of the "President's pool" (a nonofficial journalist group covering the President's activity) and televised live from Abkhasia and Chernobyl, from the North Pole and Israel Kiryat Shmona located near the Libanese border (Puminov, 2016).

For one year Dmitry Glukhowsky lived in Germany working with such channels as Deutsche Welle and Sky News (the UK). Since 2007 Glukhowsky was a host on the radio "Mayak", and in 2009 he began hosting a famous program "Fantastic Breakfast" on the Internet-channel PostTV. In 2010 he was recognized as one of the columnists of the program "Informatsiya" (eng. - "Information") on CTC TV-channel. At the same time he hosted a show "Press-Club XXI" where different cultural themes were discussed by journalists and bloggers (the program exited from April 16, 2010 till 2011 on "Kultura" (eng. - "Culture") TV-channel (LiveLib, 2016). 


\section{Literary works and the image of a modern writer}

By that time Dmitry Glukhowsky could be considered as a famous person among the fantasts. The first collections of his stories "Noch" ("Night") and "Rasskazy o zhivotnykh" ("The Stories about Animals") were written during his student-hood. At the same period of time he implemented his school idea about a post-nuclear Moscow, settlements of mysterious metro-inhabitants, mutants and anomalies. However, the novel Metro 2033 was fully rejected by all the publishers to whom Glukhowsky applied. The main idea about constant changes in the world views leading the protagonist towards a conclusion on the necessity to keep moving as the only source of believe and hope has completely ended with his death. This fact was comprehended as absolute nonsense for the work of such format. Then the unrecognized writer took a gamble - in 2002 he created a personal web-site m-e-t-r-o.boom.ru (not existing in the present time). In this site he steadily posted all the thirteen chapters of the first version of the novel (ends with the protagonist's death), besides, each chapter contained special music offered for the reading-time. The result turned out to be unprecedented - the number of readers began rapidly increase reaching the number of dozens of thousands. There were people of different professions, and those who built the underground and military people, and following their recommendations, Glukhowsky corrected the text. More often people asked to change the end and, finally, the author significantly rewrote the novel. A new version consisted of 20 chapters was posted on the same site in 2005 , and it is available there now. In the same year, Metro 2033 was published by "Eksmo", a publishing house, and the main run was of 8 thousand copies and then, an additional one, but both of them were sold immediately. In two years the book was re-published in "Populyarnaya Literatura" ("Popular Literature") (100 thousand of copies and a number of additional runs) and won the award at "Eurocon" competition as the best debut of the year. The right to film this novel was given to the Metro-Goldwyn-Mayer Corp., and the book was published abroad (and translated into 37 languages) and recorded as an audiobook. Themed on the novel people created a computer game and a series of book by different authors plotted in the world of Metro 2033.

The novel Metro 2033 resembles some kind of a cut of the world and despite the fact that it is inhabited by the citizen of only one city, the Russians mainly, it is in some sense a min-Earth. Each station or several stations interlinked by the alliance has different climate, character, structure and beliefs. They also differ between each other by the civil, cultural and technological levels. This closed underground world contains fascists, communists, revolutionaries, Jehovah's followers, tradespeople, military people, criminal and even cannibals - the whole ensemble of ideologies and statuses of the modern living society.

The plot of the novel is generally oriented in the action and introduction of the created universe, on the existence of organization in the every-day life of the following, or sometimes, absolutely different stations of the Moscow underground, as well as on changes in the citizens' consciousness. The majority of them do not remember about fresh air, green grass and the sun, which shines instead of making them blind. Those who remember dedicate themselves to their life "online": they produce electricity, grow mushrooms and raise pigs, take care of their facilities and trade. Some of them are loosed on the surface to get some survived tins with the food, medicine and clothes. The main thing is, however, is the battle for survival, the fight against creatures among which other people dominate. Since people, despite the attempts to 
preserve the civilization, lent themselves to their degradation or just unleashed those instincts which they always had inside.

In some sense Metro 2033 is also a roadnovel, since together with the protagonist, Artem, the reader walks kilometers of tunnels, over and over discovers new places and meets people of all kinds, representing highly different values and ideologies. At the same time the main character moves the way of his spirit development. Initially being an atheist, in the course of his journey he becomes convicted about the meaninglessness of living without any hope to return to the surface, to the previous, better life or without a belief in anyone or anything that cover a man and leads him from the birth till death. Due to the inner emotions of the protagonist, the book gains the depth and secondary side. Although it is written with a simple and available language, it is not only an ordinary story about the battle against the life's difficulties within the post-nuclear underground world. Glukhowsky has in detailed described the humanity collapse - both in technical, civil and moral senses. Finally, as the author claims, the life out of the higher ideas and faith turns out to be hopeless and meaningless.

The action is done dynamically, without any unnecessary stops - that together with the language has undoubtedly influenced the popularity gained by the novel. Also, the tension is created by the author steadily and skillfully, increasing the aura of mystery that fills the underground tunnels. All that forms a certain mix aimed at satisfying both the fans of dynamic plots and those who prefer higher genres.

In 2007 Dmitry Glukhowsky published his novel "Sumerki" ("Twilight") which had also been posted online in advanced. As the author says, he "tried to make this work as much different from the debut one as possible to show that he was not the one-story-author" (LiveLib, 2016). As the result we deal with a novel-metaphor, a mystification, according to the author, "full of ambiguous romanticism and mystics disguised as a thriller in which a fantastic plot touches the idea of apocalypses and ancient prophecies of Maya" (Bookmix, 2016).

In comparison with Metro 2033, the rhythm of "Twilight" is absolutely calm and smooth. In the biggest part of the novel, as it seems to be, nothing happens: together with the main character named Dmitry the reader with an increasing impatience inside is waiting for the next chapters of the chronics to be translated, in parallel, catching new messages about terrible murders and nature disasters in Moscow destroying the Earth. Only when the character starts completing the puzzle and the mysterious creatures look in his window, the action starts gathering the rate that leads to a surprising end.

Glukhowsky has perfectly managed a very hard task to attract the reader's attention by the book which is mostly deprived of the action. A precise, tensioned narration drags into Dmitry's world and allows the reader to empathize the character and when the time of the most terrible events comes - even to fear with him.

In 2014 "Twilight" won the prize by the French literature award "Utopiales".

2009 was mark by the second part of the debut Glukhowsky's novel - Metro 2034. The first sixteen chapters of the book were published one by one on a special web-site in the author's Live Journal, who described his work in the following way: "the novel Metro 2034 I prepared only by myself - I worked as the producer, advertising agent and etc. And only in the last moment the publishing house "AST" has got not only the novel, but the whole completed project. The money were spent on fees for the artist who made the design. We launched a huge number of banner posts advertising this project - from the social media to blog-services" (Proekt-Metro, 2016). 
It seems to be reasonable that Metro 2034 continues the problems asked in the first part. But this time Glukhowsky is focused on the answers and explanations of doubts. However, in the contrast to the first novel, the author has lost his light descriptions and, thus, the images of some metro-stations are not so much interesting as before. Consequently, the frontline is taken by not the world represented in the novel, but the character - Homer - an elder man who is keen on developing a history, or, a myth of a new man. Homer not only collects the underground stories - he also deliberately creates the history acting as his mythical co-brother. His work quietly transforms from a description of fact into an epos aimed at providing the future generations with a hope.

The novel Metro 2034 was also recognized as a best-seller, although the narrative style was more complex and full of philosophical metaphors, and the plot became slower and more unpredictable.

Unsurprisingly to Glukhowsky's fans, he wrote in 2010 "Rasskazy o Rodine" ("The Stories about the Motherland") representing a severe mix of realism and phantasmagoria. The author says: "The book has appeared to be on the one hand about the Motherland, since, as I think, it has been a long time since someone has updated the image of this country (...). The format came to me by itself: the novellas - a little phantasmagorical, but still actual and satirical, related to our policy and to what is going on with the country (...). The stories happen in a fiction world which much resembles this one, but differs at the same time (...). I assume that there can be a whole with one's world, one's characters who return from the story to story, meet each other, interweave. There is some sort of meta-novel consisting of 16 chapters" (Koval-Molodtsova, 2016).

"The Stories about the Motherland" resemble a certain observation on the modern
Russian society. The characters are journalists, scientists, builders and even UFO-people from another planet. No one is surprised by a stranger in the center of the city, since according to the convention of sci-fiction there is, as a rule, the secondary side and some sort of a truth about the Russians is more probable that is shown from the perspective of youngsters. On the stories charts the reader comes closer to the rules of the state's work and desires which control random politicians and engineers. Glukhowsky in a well-made manner embodies his thoughts and remarks concerning many questions related to the ordinary life of the Russians - the life which does not fill with optimism.

The stories by Glukhowsky to some extent are similar to the fantasy attempts by Gogol and Bulgakov. The time has changed, the geopolitical situation has also been transformed, but the famous "laughter through tears" is still alive. The Russian people of the 21st century resemble those who appeared in the works by the mentioned classics. Glukhowsky in his "Stories" tries to prove that the problems in the Russian society have the same matter.

Undoubtedly, "The Stories about the Motherland" represent a view on the real world by the writer with a solid experience in the international journalism in military conflicts, on TV and radio, the writer who has his own civil position. The Stories can be related to a political and social satire as well as to the modern prose containing fantastic elements - in that way, the reader has freedom to determine what and to what extent is unreal in this book. Still, the questions touched upon Glukhowsky in the collection are, definitely, topical not only in within the titled Motherland, but also in other countries.

As a return to the fiction genre we can consider the anti-utopia novel "Buduschee" ("The Future") (2013), interpreting the problem of physical immortality. "The Future" is marked 
as the anti-utopia novel. The author in one of his interviews calls this work as "the novel about a happy world, without God, churches, families, old people and children" (Kulturmultur, 2016).

It is seen from the first pages that The Future is a really true anti-utopia which continues Zamyatin's and Huxley's traditions. The world described in the novel is a new, unprecedented vision of the future. This is the space which has no place for creative, futuristic and technological achievements, does not contradict the physical laws and seems to be quite real. The main obstacle concerned in the work is the future of the human psycho and, much more likely that, it is based on certain elements of the novel's world. Any political discussions and desires of the lesser character - influential persons - demonstrate in front of the reader a huge puzzle involving the modern world's problems - political, social, psychological ones. Each of these spheres appears in the novel and is reflected in the contemporary world. At every our turn we can see incomes social gaps - people are divided into the best - the richest and the worst - the poor ones.

The other problems raised in this work are: hedonism which unites the society only for a short period of time; expansion of the world's leading powers and mass migrations; religious conflicts which show the meaninglessness of some confessions; validity of euthanasia and abortions and irrelevance of some views caused by the civilization progress. All these is ended up with the picture of invigilation of the child's mind and absence of the possibility to let him think by himself.

The novel "The Future" was firstly posted by parts on the author's VK-account and many foreign publishers have at once got the rights to translate it. Now the novel has a separate webpage which, apart from the content and pictures, also includes special music tracks for each part.
The last work created by D. Glukhowsky is Metro 2035 published in 2015.

By this long-awaited novel the writer finishes the Metro-series which is considered as the basis of the whole sub-culture (The Metro Universe) which involves not only a million readers community, but also a class of authors who continue and develop the plot of the human survival in the post-nuclear underground world.

The novel Metro 2035 misses those fantastic motives from Metro 2033: there are no monsters hidden in the corners of tunnels, psycho-traps or mutants. They are replaced by the policy, conspirations, mysterious actions of the authorities and their puppets.

Fourteen years has passed from the revolution of Metro 2033. Since that time Glukhowsky as the writer has also undergone an amazing metamorphoses. That is way Metro 2035 is considerably different from the previous parts, where the reader without the narrator's assistance completes the events and changes in the tension.

Metro 2035 can easily be analyzed through its comparison with the first part - Metro 2033 - because of the gap which separates these two novels. It can be noted that in Metro 2035 the write still develops the idea of "Time Machine" by Herbert Wells and "Roadside Picnic" by Arkady and Boris Strugatsky, but the earlier history of the road, full of sometimes funny or threatening components originated in the post-apocalyptic films, gives its place to the man's travel inside himself - an expedition which represents the main plot of the latest Dmitry Glukhowsky's work.

\section{Conclusion}

Dmitry Glukhowsky is a writer who lives in a permanent contact with the reader through the social networks, numerous interviews, meeting in bookstores as well as the articles and topical satires posted in the Internet-magazines (at the 
present time he is a columnist in such magazines as "Snob" and GQ). Moreover, he is a creator who tries to conquer the widest reader's audience. That is why his novels are different from the perspective of poetics and individual pragmatics: they seem to be an attempt to respond to the demands of different readers.

Creating separate web-sites aimed at not only giving an opportunity to read the book for free, but also making a special cooperation between the writer and his reader, Dmitry Glukhowsky has developed the image of the modern literary creator. This image represents a reflection on the reader's demands in the 21 st century - it includes the place for advertisement and for a well-made product wrapped in a highly-cost paper with graphics. All of these is available due to the most affordable source of information such as the Internet.

The surname Dmitry Glukhowsky is associated with this very product.

\section{References}

Biografija Dmitriia Glukhovskogo [Biography of Dmitry Glukhovsky]. (2016). In Bookmix. Available at: http://bookmix.ru/authors/index.phtml?id=245 (accessed December 1, 2016).

Koval-Molodtsova, J. (2016). Dmitrii Glukhovskii: Rodinu ia bezuslovno liubliu... Apdeit obraza toi strany, v kotoroi my zhiviem [Dmitry Glukhovsky: the Motherland, I definitely love... Update the image of the country in which we live]. Available at: http://www.ozon.ru/context/detail/id/5382860/ (accessed December 1, 2016).

Hanchin, D. (2016). Na zlobu grjadushhego dnja. Recenzija na knigu Dmitrija Gluhovskogo "Budushhee" [On the anger of the coming day. A review of Dmitry Glukhovsky's book "The Future"]. In Kulturmultur. Available at: http://kulturmultur.com/project/78/Na_zlobu_gryaduschego_ dnya_15_10_2013/(accessed December 1, 2016).

Dmitrij Gluh ovskij. O pisatele [Dmitry Glukhovsky. About the writer]. (2016). In LiveLib. Available at: https://www.livelib.ru/author/166037-dmitrij-gluhovskij (accessed December 1, 2016).

Rudnickij, G. (2016). Dmitrij Gluhovskij. "Content v internete reshaet mnogoe" [Dmitry Glukhovsky: "Content on the Internet decides a lot"]. In Proekt-Metro. Available at: http://proektmetro.ru/news/dmitrij_glukhovskij_kontent_v_internete_reshaet_mnogoe/2010-04-02-260 (accessed December 1, 2016).

Puminov, A. (2016). Setevoi metrostroi Dmitriia Glukhovskogo [Network metrostroy by Dmitry Glukhovsky]. In Peoples. Available at: http://www.peoples.ru/state/journalist/dmitriy_gluhovskiy (accessed December 1, 2016). 


\title{
Дмитрий Глуховский как бренд: \\ между литературным творчеством \\ и саморепрезентацией
}

\author{
Э. Козак \\ Естественно-гуманитарный университет \\ в г. Седльие \\ Польша, 08-110, Седльие, ул. Житня, 39
}

Целью работы является показать образ современного русского писателя Дмитрия Глуховского, книги которого, переведенные на десятки языков, стали основой для создания компьютерных игр и экранизаций. С достижением этого успеха связаны многие усилия, в состав которых вошло и литературное творчество, и рекламная компания.

Несомненное влияние на литературную деятельность писателя молодого поколения россиян оказало образование, опыт журналистской работы, чрезвычайно богатая фантазия, вдохновленная как ежедневными событиями, так и творчеством выдающихся представителей научно-фантастической литературы.

Основной частью нашей работы является обзор наиболее важной проблематики произведений Дмитрия Глуховского с упором на разнообразие выполняемых тем и уникальность поэтики отдельных романов и рассказов. Представлен также процесс, сопровождающий продвижение и распространение книг путем создания для них отдельных веб-странии, отличающихся неповторимым графическим и музыкальным оформлением.

Благодаря несомненной литературной ценности произведений русского писателя, а также его деятельности, направленной на то, чтобы предоставить в привлекательной и бесплатной форме содержания произведений, творчество Дмитрия Глуховского оказалось ответом на требования читателя XXI века. Благодаря подходу, который предлагает писатель, литература во всех отношениях может становиться более доступной и привлекательной.

Ключевые слова: Дмитрий Глуховский, русская литература ХХІ века, научная фантастика, литература в Интернете.

Научная специальность: 10.00.00 - филологические науки. 